\title{
Genetic diversity and structure of Silver fir (Abies alba Mill.) at the south-eastern limit of its distribution range
}

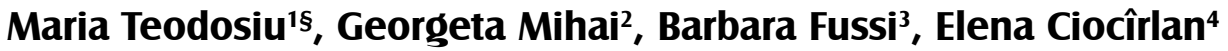

Teodosiu M., Mihai G., Fussi B., Ciocîrlan E., 2019. Genetic diversity and structure of Silver fir (Abies alba Mill.) at the south-eastern limit of its distribution range. Ann. For. Res. 62(2): 139-156.

Abstract. In the Romanian Carpathians, Silver fir covers about 5\% of the forest area and is the second most important conifer species. Although there are a number of genetic studies concerning the distribution of genetic diversity of Abies alba in Europe, populations from the south-eastern limit of the distribution range have been studied less. The aim of the present study was to assess the genetic diversity and differentiation in 36 silver fir populations along the Carpathian Mountains in Romania, using seven microsatellites loci. High levels of genetic diversity $\left(H_{e}=0.779\right.$ to 0.834 and $A_{R}=11.61$ to 14.93 ) were found in all populations. Eastern Carpathians populations show higher levels of diversity, both in allelic richness and expected heterozygosity and higher degrees of genetic differentiation compared to southern populations. Bayesian clustering analysis revealed the existence of two genetically distinct groups for silver fir populations, one larger cluster which comprises the Inner Eastern Carpathians, Curvature Carpathians, South Carpathians and the Banat Mountains and the second cluster contained most of the North and Outer Eastern Carpathians population. Both AMOVA and Barrier analysis supported genetic differentiation among geographical provenance regions. The high genetic diversity of silver fir populations from the eastern limit of its distribution provide high potential to mitigate the negative effects of climate warming being valuable genetic resources in the context of global change. The distribution pattern of genetic variation at local, regional and country scale could and should be considered for the preservation of the forest genetic resources.

Keywords: Abies alba, nuclear microsatellites markers, genetic diversity, differentiation, genetic structure

Authors. ${ }^{1}$ National Institute for Research and Developmet in Forestry "Marin Drăcea", Câmpulung Moldovenesc Research Station, Calea Bucovinei 73bis, 725100 Câmpulung Moldovenesc, Suceava, România| ${ }^{2}$ National Institute for Research and Development in Forestry "Marin Drăcea", Voluntari, 128 Eroilor Boulevard, 077190 Ilfov, România | 'Bavarian Office for Forest Genetics, Country Forstamts platz 1, 83317 Teisendorf. Germany $\mid{ }^{4}$ Department of Forest Sciences, Transilvania University of Brașov, Șirul Beethoven 1, 500123 Braşov, România

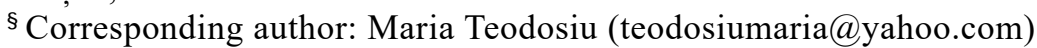

Manuscript received September 09, 2019; revised November 06, 2019; accepted November 13, 2019; online first November 26, 2019. 


\section{Introduction}

In the context of global warming, the populations living at edges of the natural species range will be the first facing climate change effects (Mátyás et al. 2009), there the main constrains are extreme temperatures, drought, edaphic conditions and water availability, which often require specific mechanisms of adaptation, resulting in natural selection of various specific quantitative traits (Howe et al. 2003). The adaptation of populations to stress conditions depends not only on selection, but also on other evolutionary factors such as migration and genetic drift (Savolainen 1996). As the evolutionary potential of species depends on spatial genetic structure and on the level of genetic diversity among and within populations, it is of the utmost importance to know the extent of genetic diversity in natural populations and the environmental determinism in assessing the species' response to expected climate change (Marchi et al. 2016; Ortego et al. 2012).

Evaluating the role of geography and environment in shaping the current genetic structure can largely contribute to disentangling the effects of local adaptive processes and spatial isolation (Wang 2013), while the assessment of the genetic structure and the identification of populations with adaptive value are a significant challenge in preserving species genetic resources (Eckert et al. 2008). In contrast to the expanding edge, the low-latitude limit (rear edge) of the species' ranges remains understudied, despite the critical importance of rear edge populations as long-term storage of species genetic diversity and foci of speciation, which has been little acknowledged (Hampe \& Petit, 2005).

The distribution of genetic variability for marginal populations was described for some species such as Scots pine (Savolainen 1996) and European beech (Ciocîrlan et al. 2017), while for Silver fir, recent studies indicate its higher adaptive capacity to mitigate climate change effects, in comparison to other coniferous species (e.g. Norway spruce, Scots pine) (Tinner et al. 2013, Rousch et al. 2016), but also the possibility of a severe growth decline in warm and dry regions of Europe (Bosela et al. 2018). At the Eastern edge of the species, the most vulnerable populations are located at low altitudes, with a pronounced precipitation deficit, such as those from the edge of the Eastern (Romanian) Carpathians and those from Banat Mountains (Mihai et al. 2018).

Genetic and palynological studies have identified three glacial refuges for Silver fir in Europe: Southern Italy, the North-West of Greece and the Pyrenees Mountains (Konnert \& Bergmann, 1995; Terhürne-Berson et al. 2004; Cheddadi et al. 2014). It is assumed that the Silver fir of Eastern Europe mostly comes from the glacial refuges located in the South of the Balkan Peninsula (Konnert \& Bergmann, 1995). The postglacial migration routes assessed by palynology concluded that Silver fir reached the Romanian range through the south of the Carpathians, occupying firstly the Western Carpathians (Apuseni and Banat Mountains), from where it subsequently migrated to the Eastern Carpathians (Diaconeasa \& Fărcaş 2001, Feurdean \& Willis 2008). Silver fir reached the Eastern Carpathians about 2500 years later than the south-west of Romania (Fărcaş et al. 2013, Tanţău et al. 2003). The hypotheses regarding the existence of glacial refuges in the Southern Carpathians (Retezat Mountain) (Magyari et al. 2012) are not supported (Postolache et al. 2016), but the existence of small/micro-refuges contributing to a rapid expansion of the species during the Holocene cannot be entirely dismissed (Vitasse et al. 2019), given the fact that a new glacial refuge was identified in the North of the Apennines and Euganean Hills in Northern Italy (Samartin et al 2016, Gubler et al. 2018).

Even though previous studies have analysed the capacity of Silver fir populations to adapt to climate change, Silver fir populations from the south-eastern edge of its distribution (e.g 
the Romanian Carpathians) still remain understudied. This location, at the convergence of three biogeographic regions (Southern, Central and Eastern Europe), together with its very diverse ecological and climatic features, make it one of the centres of highest diversity in Europe (Feurdean \& Tanțău 2017). In the Romanian Carpathians, Silver fir grows in various climatic conditions (e.g. sub-Mediterranean climate in south-west and continental climate in north) and lithological substrates. In the Eastern Carpathians, the natural distribution of silver fir overlaps with Paleocene and Cretaceous formations (marl, sandstone, clay), whereas in the Western Carpathians the metamorphic and eruptive structure of rocks (crystalline shale, granite, etc.) entail the scarcity of the Romanian silver fir (Lucău-Dănilă 1991). Pollen analysis indicates an obvious anthropogenic influence, suggesting that the substantial reduction of the area occupied by silver fir, at least in the north-eastern area, is exclusively due to clear-cutting on large surfaces in the past (Tanţău et al. 2011). The human impact on the distribution, structure and functionality of the forest has become even more noticeable in the last 300 years, the proportion of silver fir decreased by approximately $15 \%$ during this period (Barbu et al. 2015).

The aim of the paper is to assess the level of genetic diversity and genetic structure in the Silver fir populations at its Eastern distribution limit (the Romanian Carpathians), including the relative contribution of history, environmental factors and geography on current genetic variation, as a prerequisite to establishing sustainable measures for the conservation of species biodiversity. More specifically, we will try to answer the following questions. (i) Is the genetic structure of Silver fir populations homogenous, in accordance with the postglacial migration history? (ii) To what extent did anthropogenic and environmental factors influence the diversity and the current genetic structure of Silver fir? (iii) Do the Silver fir populations of the Eastern distribution limit have the capacity to persist under the expected climate changes?

\section{Materials and methods}

\section{Sampling and genotyping}

In the Romanian Carpathians, Silver fir covers about $5 \%$ of the forest area and is the second most important conifer species (Barbu \& Barbu, 2005). Almost two-thirds of the distribution area are located in the Eastern Carpathians, at altitudes spanning from $400 \mathrm{~m}$ to $1200 \mathrm{~m}$ a.s.1 where it forms pure or mixed stands with $\mathrm{Eu}-$ ropean beech and Norway spruce. In the rest of the Romanian Carpathians, Silver fir has a scattered distribution and occurs in mixed Fagus-Picea forests (Șofletea \& Curtu, 2001). In order to capture the whole ecotype variability of Silver fir in the Romanian range-i.e. thermophilic populations of Banat Mountains (Southwestern Carpathians), the populations of continental climate in Bucovina (Northern Carpathians) or those adapted to a cold climate and rainfall deficitin the Moldavian hills (Eastern Carpathians) (Sofletea \& Curtu, 2001) - we have sampled 36 Silver fir populations across the Romanian Carpathians during 2014-2016. All the sampled populations were naturally regenerated, putatively autochthonous, most being designated as Forest Genetic Resources (RGF) (Pârnuță et al. 2012) or selected seed sources (Table 1). An extensive genetic analysis was conducted on populations from the Eastern distribution range (Figure 1), mainly because this region represents the Eastern rear edge of the species distribution in Europe and, according to future projections, will be the most vulnerable in the context of climate change.

Needle or bark disks with cambium from 35 to 40 individuals, located at a distance of at least $30 \mathrm{~m}$, were collected for DNA extraction. To minimize the effect of the age factor as far as possible, sampled trees were approximately 
Table 1 Description of the 36 investigated Silver fir (Abies alba Mill.) populations

\begin{tabular}{|c|c|c|c|c|c|c|c|}
\hline \multirow[t]{2}{*}{ No } & \multirow[t]{2}{*}{ Code } & \multirow[t]{2}{*}{ Population } & \multicolumn{2}{|c|}{$\begin{array}{l}\text { Geographic } \\
\text { coordinates }\end{array}$} & \multirow{2}{*}{$\begin{array}{l}\text { Altitude } \\
\text { (m a.s.l) }\end{array}$} & \multirow[t]{2}{*}{ Bedrock } & \multirow[t]{2}{*}{$\begin{array}{l}\text { Provenance } \\
\text { region* }\end{array}$} \\
\hline & & & Latitude & Longitude & & & \\
\hline 1 & POI & Poieni & $47^{\circ} 52^{\prime}$ & $24^{\circ} 36^{\prime}$ & 950 & Crystalline shale & A1 \\
\hline 2 & STB & Strâmbu Băiuţ & $47^{\circ} 38^{\prime}$ & $24^{\circ} 00^{\prime}$ & 800 & Igneous & A1 \\
\hline 3 & LIB & Liban & $46^{\circ} 28^{\prime}$ & $25^{\circ} 22^{\prime}$ & 720 & Igneous & A1 \\
\hline 4 & TOP & Topliţa & $47^{\circ} 00^{\prime}$ & $25^{\circ} 16^{\prime}$ & 1100 & Igneous & A3 \\
\hline 5 & FRU & Frumoasa & $46^{\circ} 21^{\prime}$ & $25^{\circ} 41^{\prime}$ & 920 & Marl & A3 \\
\hline 6 & TUS & Tuşnad & $46^{\circ} 09^{\prime}$ & $25^{\circ} 51^{\prime}$ & 700 & Igneous & A3 \\
\hline 7 & DEM & Demăcuşa & $47^{\circ} 41^{\prime}$ & $25^{\circ} 25^{\prime}$ & 1100 & Flysch & A2 \\
\hline 8 & STU & Stulpicani & $47^{\circ} 25^{\prime}$ & $25^{\circ} 39^{\prime}$ & 900 & Phyllite & A2 \\
\hline 9 & BRA & Brateş & $46^{\circ} 50^{\prime}$ & $26^{\circ} 10^{\prime}$ & 850 & Flysch & A2 \\
\hline 10 & MOI & Moineşti & $46^{\circ} 37^{\prime}$ & $26^{\circ} 24^{\prime}$ & 800 & Clay & $\mathrm{A} 2$ \\
\hline 11 & PUT & Putna & $47^{\circ} 51^{\prime}$ & $25^{\circ} 38^{\prime}$ & 650 & Flysch & $\mathrm{A} 2$ \\
\hline 12 & MAR & Marginea & $47^{\circ} 48^{\prime}$ & $25^{\circ} 42^{\prime}$ & 670 & Flysch & $\mathrm{A} 2$ \\
\hline 13 & SOL & Solca & $47^{\circ} 45^{\prime}$ & $25^{\circ} 48^{\prime}$ & 500 & Marl & $\mathrm{A} 2$ \\
\hline 14 & GHU & Gura Humorului & $47^{\circ} 38^{\prime}$ & $25^{\circ} 47^{\prime}$ & 730 & Flysch & $\mathrm{A} 2$ \\
\hline 15 & MAL & Mălini & $47^{\circ} 24^{\prime}$ & $26^{\circ} 01^{\prime}$ & 550 & Sandstone & $\mathrm{A} 2$ \\
\hline 16 & RAS & Râşca & $47^{\circ} 20^{\prime}$ & $26^{\circ} 07^{\prime}$ & 500 & Marl & $\mathrm{A} 2$ \\
\hline 17 & VAR & Văratec & $47^{\circ} 08^{\prime}$ & $26^{\circ} 15^{\prime}$ & 600 & Flysch & $\mathrm{A} 2$ \\
\hline 18 & GAR & Gârcina & $46^{\circ} 58^{\prime}$ & $26^{\circ} 19^{\prime}$ & 550 & Marl & $\mathrm{A} 2$ \\
\hline 19 & TAZ & Tazlău & $46^{\circ} 41^{\prime}$ & $26^{\circ} 22^{\prime}$ & 550 & Flysch & $\mathrm{A} 2$ \\
\hline 20 & $\mathrm{MNC}$ & Caşin & $46^{\circ} 05^{\prime}$ & $26^{\circ} 45^{\prime}$ & 520 & Clay & A2 \\
\hline 21 & CAI & Căiuţi & $46^{\circ} 05^{\prime}$ & $26^{\circ} 50^{\prime}$ & 500 & Clay & A2 \\
\hline 22 & SOV & Soveja & $47^{\circ} 59^{\prime}$ & $26^{\circ} 38^{\prime}$ & 550 & Sandstone & $\mathrm{B} 2$ \\
\hline 23 & VID & Vidra & $46^{\circ} 00^{\prime}$ & $26^{\circ} 44^{\prime}$ & 520 & Sandstone & $\mathrm{B} 2$ \\
\hline 24 & VIN & Vintileasca & $45^{\circ} 37^{\prime}$ & $26^{\circ} 38^{\prime}$ & 1050 & Flysch & $\mathrm{B} 2$ \\
\hline 25 & CHE & Cheia & $45^{\circ} 27^{\prime}$ & $25^{\circ} 55^{\prime}$ & 920 & Flysch & B2 \\
\hline 26 & AZU & Azuga & $45^{\circ} 25^{\prime}$ & $25^{\circ} 32^{\prime}$ & 950 & Flysch & B2 \\
\hline 27 & $\mathrm{COV}$ & Covasna & $45^{\circ} 53^{\prime}$ & $26^{\circ} 15^{\prime}$ & 900 & Flysch & B1 \\
\hline 28 & AVR & Avrig & $45^{\circ} 39^{\prime}$ & $24^{\circ} 29^{\prime}$ & 750 & Crystalline shale & $\mathrm{C} 1$ \\
\hline 29 & LAP & Lapusnic & $45^{\circ} 18^{\prime}$ & $22^{\circ} 43^{\prime}$ & 1200 & Sandstone & $\mathrm{C} 1$ \\
\hline 30 & LUP & Lupeni & $45^{\circ} 18^{\prime}$ & $23^{\circ} 02^{\prime}$ & 800 & Crystalline shale & $\mathrm{C} 1$ \\
\hline 31 & TIS & Tismana & $45^{\circ} 08^{\prime}$ & $22^{\circ} 54^{\prime}$ & 720 & Granite & $\mathrm{C} 2$ \\
\hline 32 & ANI & Anina & $45^{\circ} 04^{\prime}$ & $21^{\circ} 53^{\prime}$ & 650 & Calcareous & D1 \\
\hline 33 & DOB & Dobra & $45^{\circ} 40^{\prime}$ & $22^{\circ} 30^{\prime}$ & 1100 & Crystalline shale & D2 \\
\hline 34 & RMO & Rusca Montană & $45^{\circ} 39^{\prime}$ & $22^{\circ} 22^{\prime}$ & 1000 & Crystalline shale & $\mathrm{D} 2$ \\
\hline 35 & REM & Remeţi & $46^{\circ} 46^{\prime}$ & $22^{\circ} 34^{\prime}$ & 850 & Igneous & E2 \\
\hline
\end{tabular}


Table 1 (continuation)

\begin{tabular}{l}
$\begin{array}{l}36 \\
\text { ABR Abrud }\end{array} 6^{\circ} 20^{\prime} \quad 2^{\circ} 06^{\prime} \quad 950 \quad$ Flysch \\
\hline Note. Abbreviations: A1 - Inner Eastern Carpathians; A2 - Outer Eastern Carpathians; A3 - Eastern Carpath- \\
ians: Giurgeu-Ciuc Depression; B1 - Curvature Carpathians: Braşov Depression; B2 - Curvature Carpathians; \\
C1 - Southern Carpathians: northern part; C2 - Southern Carpathians: southern part; D1 - Banat Mountains: \\
Mehedinţi-Cerna-Semenic; D2 - Banat Mountains: Țarcu-Poiana Ruscă; E2 - Apuseni Mountains: western part; \\
E3 - Apuseni Mountains: eastern part
\end{tabular}

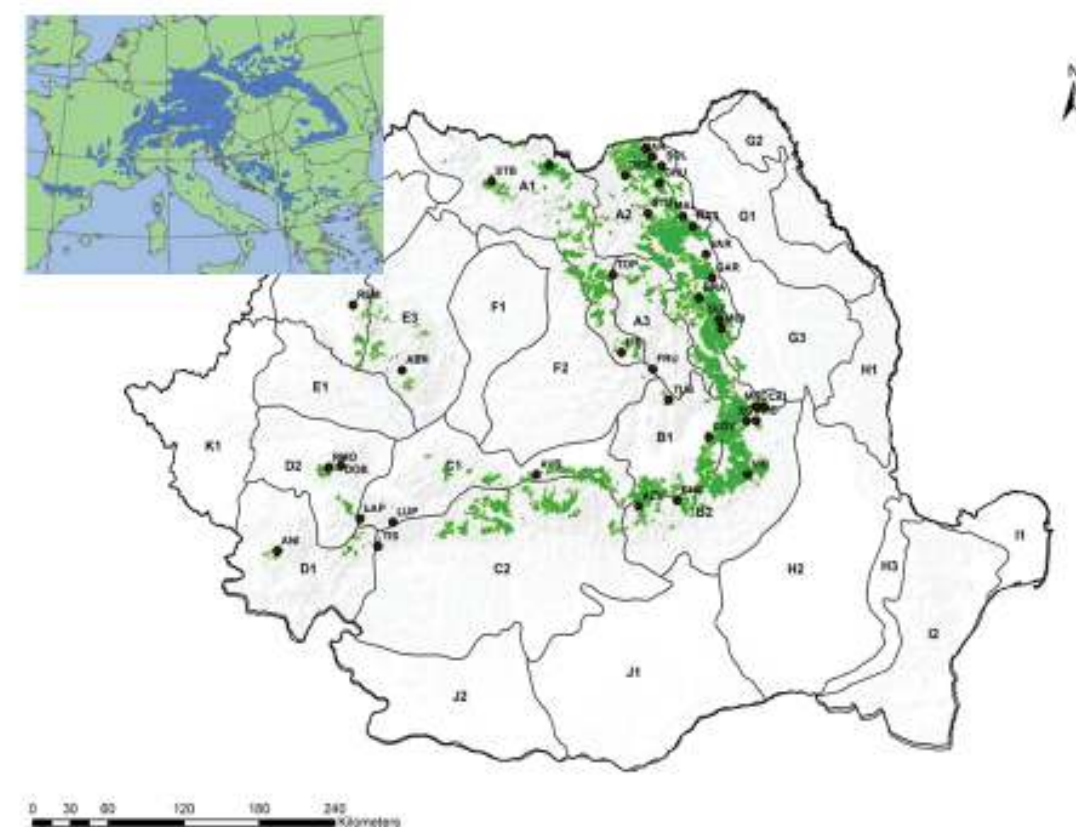

Figure 1 Current natural distribution range of Abies alba in Romania and geographical locations of 36 populations used in the present study. The inset shows the species range in Europe (EUFORGEN). The code of the populations and provenance region are given in the Table 1. The distribution map were generated according to the main type of the silver fir forest ecosystem in Romania.

100 years old. The material was dried in silica gel and stored at $-70^{\circ} \mathrm{C}$ before analysis.

Genomic DNA was extracted following methods of Dumolin et al. (1995). Genotyping was based on seven neutral microsatellites markers: four developed for Abies nordmanniana (NFH3, NFH15, NFF7 and NFF3) (Hansen at al. 2005) and three developed for Abies alba (Sf1, Sfb4 and Sf78) (Cremer et al. 2006). These seven microsatellite loci were separated into two multiplex combinations. For the PCR reactions we used the Qiagen Type-it Microsatellite PCR Kit (Qiagen, Germany) which is optimized and ready-to-use master mix. The multiplex reactions were set up as $15 \mu \mathrm{l}$ PCR mix containing $7.5 \mu \mathrm{l}$ Qiagen multiplex PCR buffer $(2 \mathrm{x}), 1.5 \mu 1$ primer mix, $1 \mu \mathrm{IDNA}$ (30-50 ng genomic DNA) and $5 \mu 1$ Rnase free-water. Concentrations of primers were $0.05 \mu \mathrm{mol}$ NFF7, $\quad 0.40 \quad \mu \mathrm{mol}$ NFH3 and $0.40 \mu \mathrm{mol}$ NFF3 in multiplex A; $0.10 \mu \mathrm{mol} \mathrm{Sfb} 4,0.20$ $\mu \mathrm{mol} \mathrm{Sf78,0.20 \mu \textrm {mol }}$ Sf1 and $0.20 \mu \mathrm{mol}$ NFH15. The PCR reactions were run in Palm-Cycler (Corbbet) using the following program: $15 \mathrm{~min}$. at $95^{\circ} \mathrm{C}$, followed by 27 cycles for $30 \mathrm{sec}$ at $94^{\circ} \mathrm{C}, 1.30 \mathrm{~min}$ at $57^{\circ} \mathrm{C}$ and $30 \mathrm{sec}$ at $72^{\circ} \mathrm{C}$ and a final extension step for $30 \mathrm{~min}$ at $60^{\circ} \mathrm{C}$. Obtained PCR products were analysed by a GeXP Genetic Analysis System (Beckman Coulter Inc., USA). Genotypes were scored using Genomelab software ver. 10.2.3 (Beckman Coulter). The used microsatellites have dinucleotide repeats, except Sf1 with trinucleotide repeats.

Microsatellite data were first checked regarding the presence of null alleles and genotyping errors through Micro-Checker 2.2.3 
software (van Oosterhout et al. 2004). Linkage disequilibrium and significant deviations from Hardy-Weinberg equilibrium in nSSR loci were tested with Genepop (Rousset 2008) and FSTAT ver. 2.9.3 (Goudet 1995), respectively. We estimated main parameters of genetic diversity: mean number of alleles per locus: $\left(N_{a}\right)$, rarefied allelic richness for 35 diploid individuals; $\left(A_{R}\right)$, number of private alleles $\left(A_{P}\right)$, observed heterozygosity; $\left(H_{o}\right)$, expected heterozygosity; $\left(H_{e}\right)$ and inbreeding coefficient; $\left(F_{I S}\right)$ with the software FSTAT ver. 2.9.3 (Goudet 1995) and Arlequin ver. 3.5 (Excoffier \& Lischer 2010). The significance level of $\mathrm{F}_{\text {IS }}$ 's deviation from zero was calculated based on 5000 randomization using FSTAT ver. 2.9.3 (Goudet 1995).

\section{Genetic structure}

Genetic differentiation among the 36 Silver fir populations was estimated by pairwise $F_{S T}$ (Weir \& Cockerham, 1984) using Arlequin 3.5.2 (Excoffier et al. 2005), graphically represented with the web server tool Heatmapper (Babicki et al. 2016); the $F_{S T}$ significance was tested by 10000 permutations. Based on pairwise $F_{S T}$ value, a neighbour-joining tree was constructed in the software SPLITSTREE 4.13.1 (Huson, 1998). Further, to determine the percentage of within and among population genetic variation, we conducted an analysis of molecular variance (AMOVA). Then, the populations were grouped as follows: (i) by the different geographical regions of the Carpathians: NEC - North-eastern Carpathians, CC - Curvature Carpathians, SC - Southern Carpathians and SWC - South-western Carpathians) and (ii) by the homogeneous groups resulted from STRUCTURE version 2.3.4 (Pritchard et al. 2009), where $K=2$ and the cluster affiliation of individuals was greater than 0.6. Based on this, three levels of AMOVA were performed and the molecular variation was partitioned among groups $\left(F_{C T}\right)$, among populations within groups $\left(F_{S C}\right)$ and among populations $\left(F_{S T}\right)$. The individual-based genetic structure was assessed by the Bayesian clustering method, as implemented in STRUCTURE; simulations were run 5 times for each value of $\mathrm{K}$ (1-10) for 100000 iterations after a burn-in period of 100000 iterations with the LOCPRIOR model and admixture ancestral model. The best number of different clusters using $\Delta \mathrm{K}$ parameter (Evanno et al. 2005) was determined with STRUCTURE HARVESTER v. 0.6.94 (Earl \& von Holdt 2012), while the graphical representation of STRUCTURE results was based on the web application POPHELPER (Francis 2016).

\section{Landscape genetics}

The isolation by distance (IBD) hypothesis was tested by performing a Mantel test between the matrix of pairwise $F_{S T}$ and geographical distances, with 9999 random permutations, using GenAlEx 6.5 (Peakall \& Smouse 2012). To avoid problems caused by population structure, because the test of IBD could be strongly influenced by it (Meirmans, 2012), we tested the IBD separately for each cluster obtained by STRUCTURE analysis.

To identify important discontinuities and barriers in the distribution of genetic diversity we used two methods of boundary detection (Blair et al. 2012). First, a Genetic Landscape Shapes analysis was conducted using the software ALLELES IN SPACE (AIS) (Miller, 2005), by constructing a Delaunay triangulation network between Silver fir populations based on geographic coordinates, and the calculation of average genetic distances, followed by an interpolation procedure to infer genetic distances to sample locations. Within the resulting three-dimensional plot, $\mathrm{X}$ and $\mathrm{Y}$ are the sample coordinates and Z (surface plot heights) correspond to the genetic distances.

The Monmonier's maximum distance algorithm, as implemented in BARRIER version 2.2 (Manni et al. 2004), was also employed to search for genetic barriers. The geographical 
coordinates of each sampled Silver fir population were connected by a Delauney triangulation and the corresponding Voronoï tessellation was derived. Further, the pairwise associated Nei's genetic distances $\left(D_{A}\right)$ were calculated in MSA software (Dieringer \& Schlötterer 2003) and 100 bootstrap replicates of the distance matrix were used to calculate the statistical significance of the predicted barriers. We tested $N$ $=6$ barriers, in accordance with the maximum possible number of clusters obtained from the STRUCTURE analysis (see Figure 4). Finally, only the genetic barriers with over $80 \%$ bootstrap support were represented.

\section{Results}

\section{Population genetic diversity}

Across all the populations, the seven loci analysed were highly polymorphic, with a total number of alleles of 214. The number of alleles per locus $\left(N_{a}\right)$ ranged from 9 (locus Sf1) to 58 (locus Sf78), while the observed heterozygosity $\left(H_{o}\right)$ value varied from 0.452 (Sf1) to 0.905 (NFF7) (Table 2). Data analysis of each population revealed presence of null alleles for three different loci (Sf1, Sfb4 and Sf78), within nine populations, and for two loci (Sfb4 and NFH15) within two populations (data not shown). The frequency of null alleles was less than $10 \%$, with an average of $7 \%$, and all loci were maintained for further analysis. Significant linkage disequilibrium $(p<0.001)$ was detected for three of the marker combinations: NFH3 and Sf78 in population BRA, NFH3 and NFH15 in population SOV, and NFH3 and NFF7 in population VID.

The parameters of genetic diversity of the silver fir populations are presented in Table 3 . The mean number of detected alleles per locus $\left(N_{a}\right)$ ranged from 11.85 (VID) to 15.57 (AVR), with an average value of 14.02. The lowest value of rarefied allelic richness $\left(A_{R}\right)$ was found in VID (11.61) and the highest of 14.93 in AVR. The observed heterozygosity $\left(H_{o}\right)$ value ranged from 0.779 (AZU population) to 0.834 (REM population). Private allele analysis revealed 21 alleles, the maximum number of 2 alleles being found in the northern population POI, eastern population VID and in three populations of the south-west region (TIS, ANI and ABR). The lowest values of the inbreeding coefficient $\left(F_{I S}\right)$ value $(-0.072)$ were in the Inner Eastern Carpathians (TUS and COV) which indicates a significant excess of heterozygotes $(p<0.01)$ (Table 3), and the highest $(0.081, \mathrm{p}<0.001)$ in south-western Carpathians (Banat Mountains, population ANI).

In general, a higher level of genetic diversity, both allelic richness and expected heterozy-

Table 2 Characterization of nSSR loci used in analysis

\begin{tabular}{llllllll}
\hline No & Locus & $\begin{array}{l}\text { Observed fragment } \\
\text { length (bp) }\end{array}$ & \multicolumn{1}{l}{$N_{a}$} & \multicolumn{1}{l}{$H_{o}$} & \multicolumn{1}{l}{$H_{e}$} & \multicolumn{1}{l}{$F_{I S}$} & $F_{S T}$ \\
\hline 1 & NFH3 & $91-191$ & $19.69 \pm 0.26$ & $0.894 \pm 0.008$ & $0.883 \pm 0.005$ & $-0.012 \pm 0.008$ & 0.026 \\
\hline 2 & NFH15 & $98-140$ & $11.69 \pm 0.23$ & $0.810 \pm 0.012$ & $0.801 \pm 0.008$ & $-0.011 \pm 0.012$ & 0.030 \\
\hline 3 & NFF3 & $111-157$ & $9.47 \pm 0.21$ & $0.814 \pm 0.010$ & $0.800 \pm 0.005$ & $-0.017 \pm 0.012$ & 0.028 \\
\hline 4 & NFF7 & $116-176$ & $17.19 \pm 0.28$ & $0.905 \pm 0.008$ & $0.898 \pm 0.003$ & $-0.007 \pm 0.009$ & 0.023 \\
\hline 5 & Sf78 & $161-291$ & $20.72 \pm 0.36$ & $0.890 \pm 0.011$ & $0.907 \pm 0.003$ & $0.020 \pm 0.011$ & 0.028 \\
\hline 6 & Sfb4 & $143-199$ & $15.36 \pm 0.33$ & $0.845 \pm 0.011$ & $0.853 \pm 0.004$ & $0.010 \pm 0.013$ & 0.027 \\
\hline 7 & Sf1 & $206-230$ & $4.02 \pm 0.18$ & $0.442 \pm 0.015$ & $0.452 \pm 0.009$ & $0.022 \pm 0.028$ & 0.021 \\
\hline
\end{tabular}

Note. Abbreviations: $N_{a}$ - number of alleles per locus, $H_{o}$ - observed heterozygosity, $H_{e}$ - expected heterozygosity, $F_{I S}$ - inbreeding coefficient, $F_{S T}$ - coefficient of differentiation. 
Table 3 Genetic diversity statistics on the basis of seven nuclear microsatellites loci (nSSR)

\begin{tabular}{|c|c|c|c|c|c|c|c|}
\hline Populations & $N$ & $N_{a}$ & $A_{R}$ & $A_{P}$ & $H_{o}$ & $H_{e}$ & $F_{I S}$ \\
\hline POI & 40 & 14.85 & 14.36 & 2 & 0.840 & 0.833 & -0.008 \\
\hline STB & 40 & 14.00 & 13.47 & 1 & 0.814 & 0.828 & 0.017 \\
\hline LIB & 40 & 14.00 & 13.52 & 0 & 0.786 & 0.798 & 0.016 \\
\hline TOP & 40 & 14.14 & 13.69 & 0 & 0.785 & 0.799 & 0.019 \\
\hline FRU & 40 & 13.57 & 13.16 & 0 & 0.823 & 0.805 & -0.021 \\
\hline TUS & 40 & 14.00 & 13.39 & 0 & 0.846 & 0.789 & $-0.072 * *$ \\
\hline TOM & 40 & 14.42 & 13.86 & 1 & 0.786 & 0.822 & $0.045^{*}$ \\
\hline STU & 40 & 14.28 & 13.73 & 0 & 0.775 & 0.807 & 0.040 \\
\hline PUT & 40 & 13.85 & 13.41 & 0 & 0.846 & 0.819 & -0.033 \\
\hline MAR & 40 & 14.71 & 14.12 & 0 & 0.814 & 0.817 & 0.004 \\
\hline SOL & 40 & 13.71 & 13.14 & 1 & 0.793 & 0.827 & 0.042 \\
\hline GHM & 40 & 14.14 & 13.66 & 0 & 0.775 & 0.820 & $0.055^{*}$ \\
\hline MAL & 40 & 13.00 & 12.65 & 0 & 0.836 & 0.813 & -0.028 \\
\hline RAS & 40 & 13.28 & 12.81 & 1 & 0.793 & 0.822 & 0.036 \\
\hline VAR & 40 & 14.14 & 13.60 & 1 & 0.804 & 0.814 & 0.013 \\
\hline GAR & 40 & 14.28 & 13.77 & 0 & 0.796 & 0.831 & $0.043^{*}$ \\
\hline BRA & 40 & 15.28 & 14.69 & 1 & 0.811 & 0.816 & 0.007 \\
\hline TAZ & 40 & 13.57 & 13.16 & 0 & 0.789 & 0.831 & $0.051^{*}$ \\
\hline MOI & 40 & 13.42 & 12.93 & 0 & 0.800 & 0.815 & 0.020 \\
\hline CAS & 35 & 13.00 & 13.00 & 0 & 0.788 & 0.789 & 0.003 \\
\hline CAI & 40 & 13.85 & 13.28 & 0 & 0.814 & 0.800 & -0.017 \\
\hline SOV & 40 & 14.28 & 13.74 & 0 & 0.793 & 0.806 & 0.017 \\
\hline VID & 40 & 11.85 & 11.61 & 2 & 0.781 & 0.797 & 0.021 \\
\hline VIN & 40 & 14.00 & 13.40 & 0 & 0.772 & 0.813 & $0.051^{*}$ \\
\hline $\mathrm{CHE}$ & 40 & 14.28 & 13.82 & 0 & 0.810 & 0.803 & -0.008 \\
\hline$\overline{A Z U}$ & 40 & 14.00 & 13.44 & 0 & 0.766 & 0.779 & 0.018 \\
\hline $\mathrm{COV}$ & 40 & 14.14 & 13.58 & 1 & 0.868 & 0.809 & $-0.072 * *$ \\
\hline AVR & 40 & 15.57 & 14.93 & 1 & 0.828 & 0.821 & -0.009 \\
\hline LUP & 40 & 14.57 & 13.91 & 1 & 0.821 & 0.809 & -0.015 \\
\hline LAP & 40 & 14.14 & 13.56 & 1 & 0.793 & 0.804 & 0.015 \\
\hline TIS & 40 & 13.85 & 13.32 & 2 & 0.782 & 0.784 & 0.003 \\
\hline ANI & 40 & 14.42 & 13.85 & 2 & 0.729 & 0.794 & $0.083^{* * *}$ \\
\hline DOB & 40 & 13.28 & 12.88 & 0 & 0.800 & 0.801 & 0.002 \\
\hline $\mathrm{RMO}$ & 40 & 14.28 & 13.61 & 0 & 0.775 & 0.789 & 0.018 \\
\hline $\mathrm{ABR}$ & 40 & 14.57 & 13.87 & 2 & 0.761 & 0.793 & 0.041 \\
\hline REM & 40 & 14.00 & 13.51 & 1 & 0.800 & 0.834 & 0.041 \\
\hline
\end{tabular}


Table 3 (continuation)

\begin{tabular}{llllll}
\hline Overall & 14.02 & 13.51 & 0.800 & 0.810 & 0.012
\end{tabular}

Note. Abbreviations: $N$ - sample size, $N_{a}$ - mean number of alleles per locus, $A_{R}$ - rarefied allelic richness, $A_{P}$ number of private alleles, $H_{o}$ - observed heterozygosity, $H_{e}$ - expected heterozygosity, $F_{I S}$ - inbreeding coefficient. Significance: $\left.{ }^{*} p<0.05,{ }^{* *} p<0.01, * * * p<0.001\right)$.
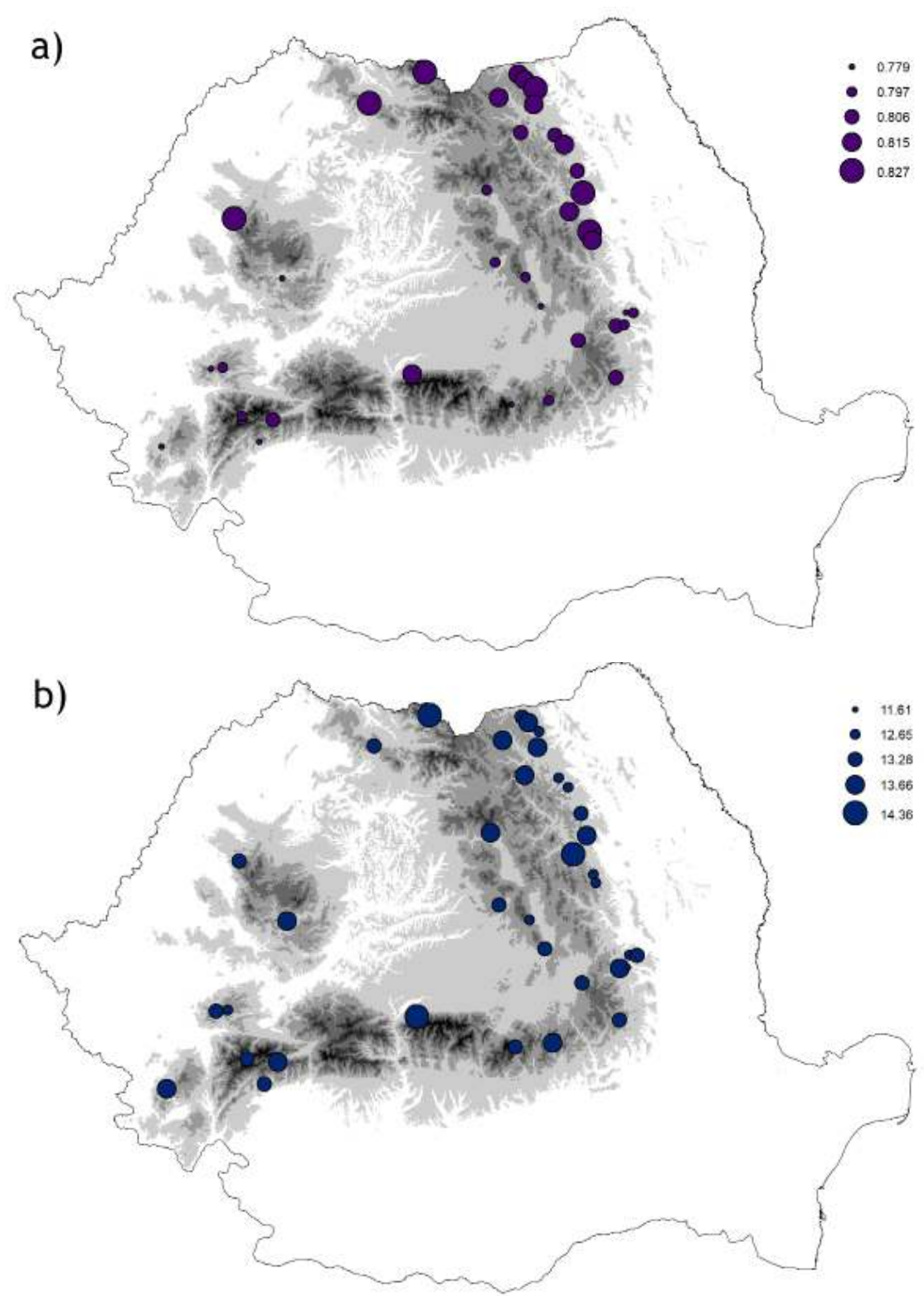

Figure 2 Spatial distribution of genetic diversity across Romanian silver fir populations. a) Expected heterozygosity $\left(H_{e}\right)$; b) allelic richness $\left(A_{R}\right)$ ern and Outer Eastern Carpathians (Figure 2a). The same pattern was revealed by allelic richness $\left(A_{R}\right)$, but the differences were not as striking as in the case of expected heterozygosity $\left(H_{e}\right)$ (Figure 2b).

\section{Population differentia- tion}

The level of genetic differentiation among the analysed populations was relatively low $\left(F_{S T}\right.$ $=0.014$ ) (Table 4, Figure $3)$, though more than half $(65 \%)$ of the pairwise $\mathrm{F}_{S T}$ ramping were significant $(p<0.001)$, from 0.001 to 0.036 . The highest differentiation was found between eastern population CAS and south population TIS. The lowest values were obtained between nearby populations such as MAL and RAS, CAS and CAI as well as between the western population $\mathrm{RMO}$ and four populations from the south-western region (AVR, LUP, ANI and gosity $\left(H_{e}\right)$ was found in the Eastern Carpathian populations (Figure 2), with the highest expected heterozygosity $\left(H_{e}\right)$ occurring in the North-
DOB). The matrix of pairwise $F_{S T}$ (Figure 3) shows that the differentiation between populations in the interior of the north-eastern and the 
Table 4 Analysis of hierarchical molecular variance (AMOVA) for 36 silver fir populations based on nSSR (a) all populations, (b) among provenances region and c) among genetic clusters inffered by STRUCTURE

\begin{tabular}{llllll}
\hline Source of variation & $d f$ & Sum of squares & Variance components & $\%$ variation & $F$-statistics \\
\hline a) & & & & 1.452 & $0.014^{* * *}$ \\
\hline Among populations & 35 & 215.447 & 0.04176 & 98.547 & \\
\hline Within populations & 2830 & 8012.751 & 2.833 .62 & 0.438 & $0.004^{* * *}$ \\
\hline b) & & & & 1.178 & $0.011^{* * *}$ \\
\hline $\begin{array}{l}\text { Among provenances } \\
\left(F_{C T}\right)\end{array}$ & 3 & 38.400 & 0.01264 & 98.383 & $0.016^{* * *}$ \\
\hline $\begin{array}{l}\text { Among populations } \\
\text { within provenances }\left(F_{S C}\right)\end{array}$ & 32 & 177.084 & 0.03394 & & \\
\hline Within populations $\left(F_{S T}\right)$ & 2830 & 8012.751 & 2.83362 & 0.760 & $0.007^{* * *}$ \\
\hline c) & 1 & 33.445 & 0.02193 & 1.073 & $0.010^{* * *}$ \\
\hline $\begin{array}{l}\text { Among clusters } \\
\left(F_{C T}\right)\end{array}$ & 31 & 164.145 & 0.03097 & 98.16 & $0.018^{* * *}$ \\
\hline $\begin{array}{l}\text { Among populations } \\
\text { within clusters }\left(F_{S C}\right)\end{array}$ & 2593 & 7338.076 & 2.83242 & & \\
\hline \begin{tabular}{l} 
Within populations $\left(F_{S T}\right)$ \\
\hline
\end{tabular}
\end{tabular}

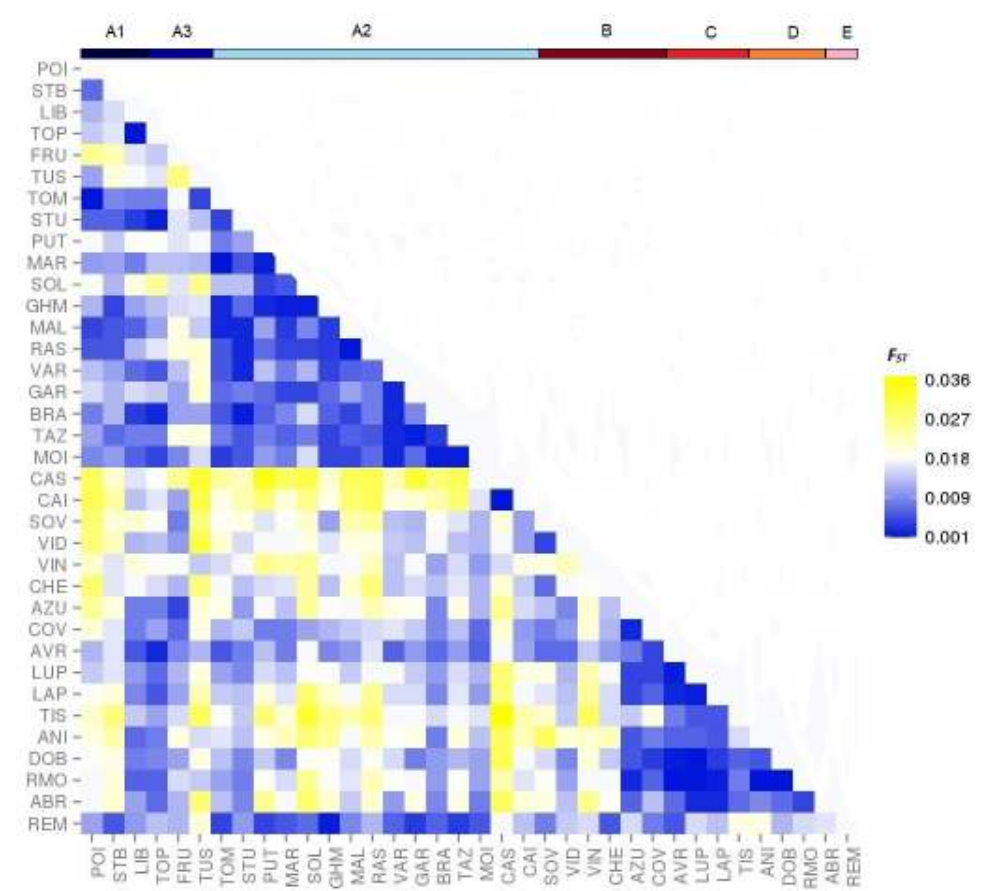

Figure 3 Pairwise genetic differentiation among silver fir populations (A1 - Inner Eastern Carpathians; A2 - Outer Eastern Carpathians; A3 - Eastern Carpathians: Giurgeu-Ciuc Depression; B - Curvature Carpathians; C - Southern Carpathians; D - Banat Mountains; E Apuseni Mountains) south-western groups is lower, in comparison with the central range (Southern Carpathians).

The analysis of molecular variance revealed that only a small proportion of the genetic diversity was found among populations, $98 \%$ value of genetic diversity being found within populations. The AMOVA analysis, performed after grouping silver fir populations according to the provenance regions and genetic clusters respectively, shows similar results, with only $0,43 \%$, respectively $0,76 \%$ of the variation distributed among groups, and the same significant proportion $(p<0.0001)$ of the genetic variation found within populations ( 98\%) (Table 4).

The STRUCTURE analysis identified two distinct genetic clusters $(\mathrm{K}=2)$ (Figure $4 \mathrm{a})$. The 
a)

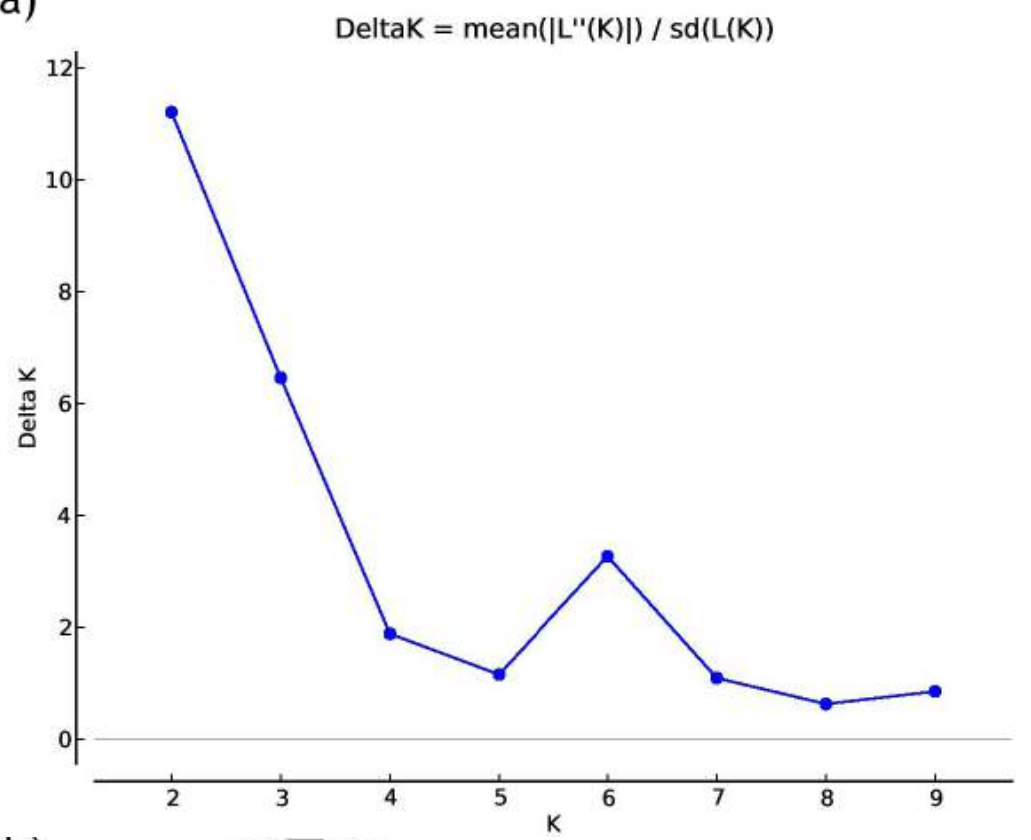

b)

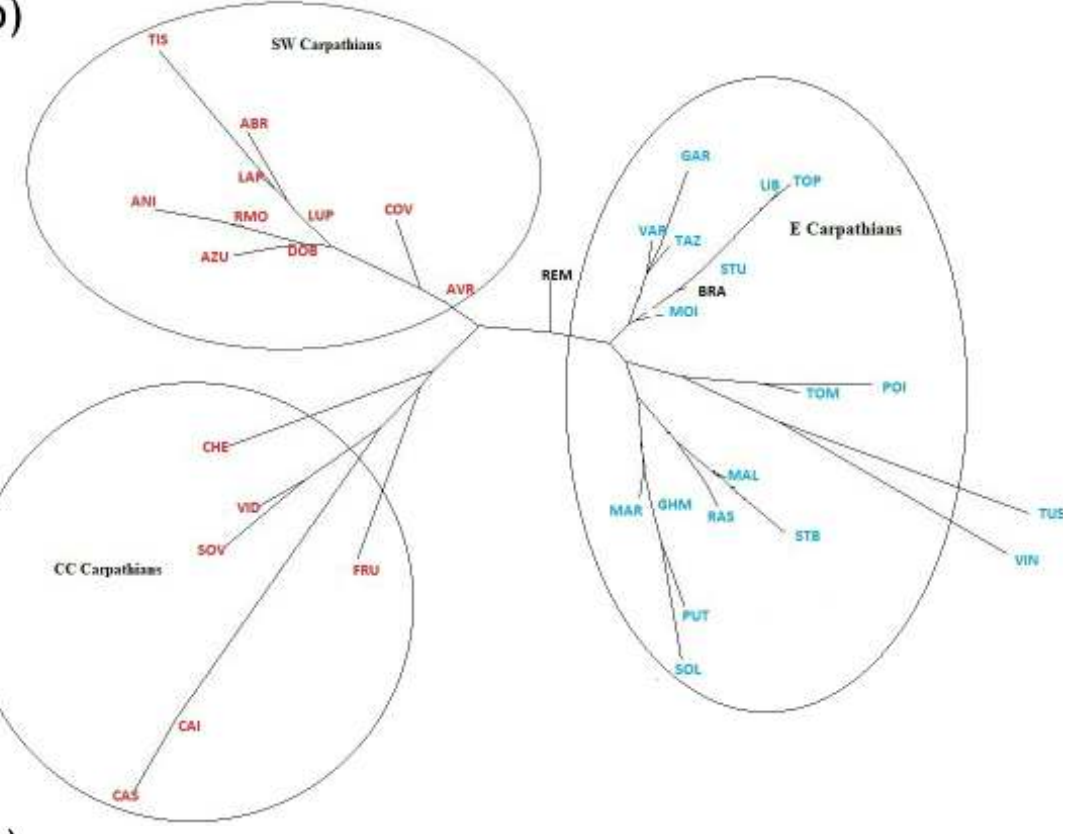

largest cluster (red color in Figure 4c) included most of the populations of the Curvature Carpathians (B), South Carpathians (C) and the Banat Mountains (D) with two exception, populations REM (Apuseni Mountains) and VIN (Curvature Carpathians) which clustered with the second major cluster. This first major cluster was further subdivided into a south-eastern subgroup (Curvature Carpathians) and a south-western group (South Carpathians and Banat Mountains) (Figure $4 \mathrm{c}$ ). The second major(blue color in Figure 4c) cluster contained most of the Outer Eastern Carpathians (A2) populations and Inner Eastern Carpathians (A1 and A3). However, inside the Eastern Carpathians the proportion of admixture is more pronounced than in the south-western region.

The Neighbour-joining tree indicates similar patterns with STRUCTURE,

C)
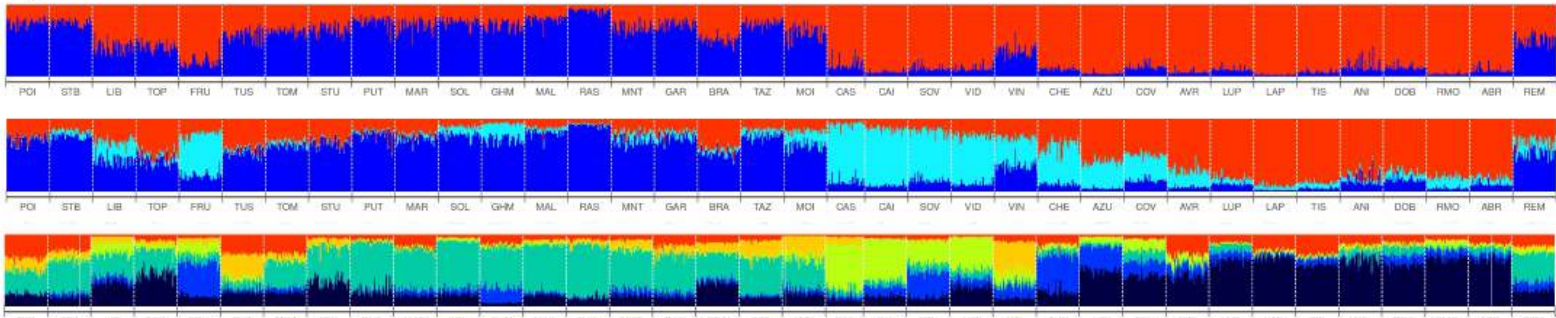

Figure 4 Population structure inferred from a model based Bayesian cluster analysis and Neighbor-joining tree a) graph of delta $\mathrm{K}$ with a distinct peak at $\mathrm{K}=2$ two minor peaks at $\mathrm{K}=3$ and $\mathrm{K}=6, \mathrm{~b}$ ) neighbor-joining phylogenetic tree, c) genetic structure of the 36 silver fir populations for different inferred K. Different inferred populations are distinguished by different colors 


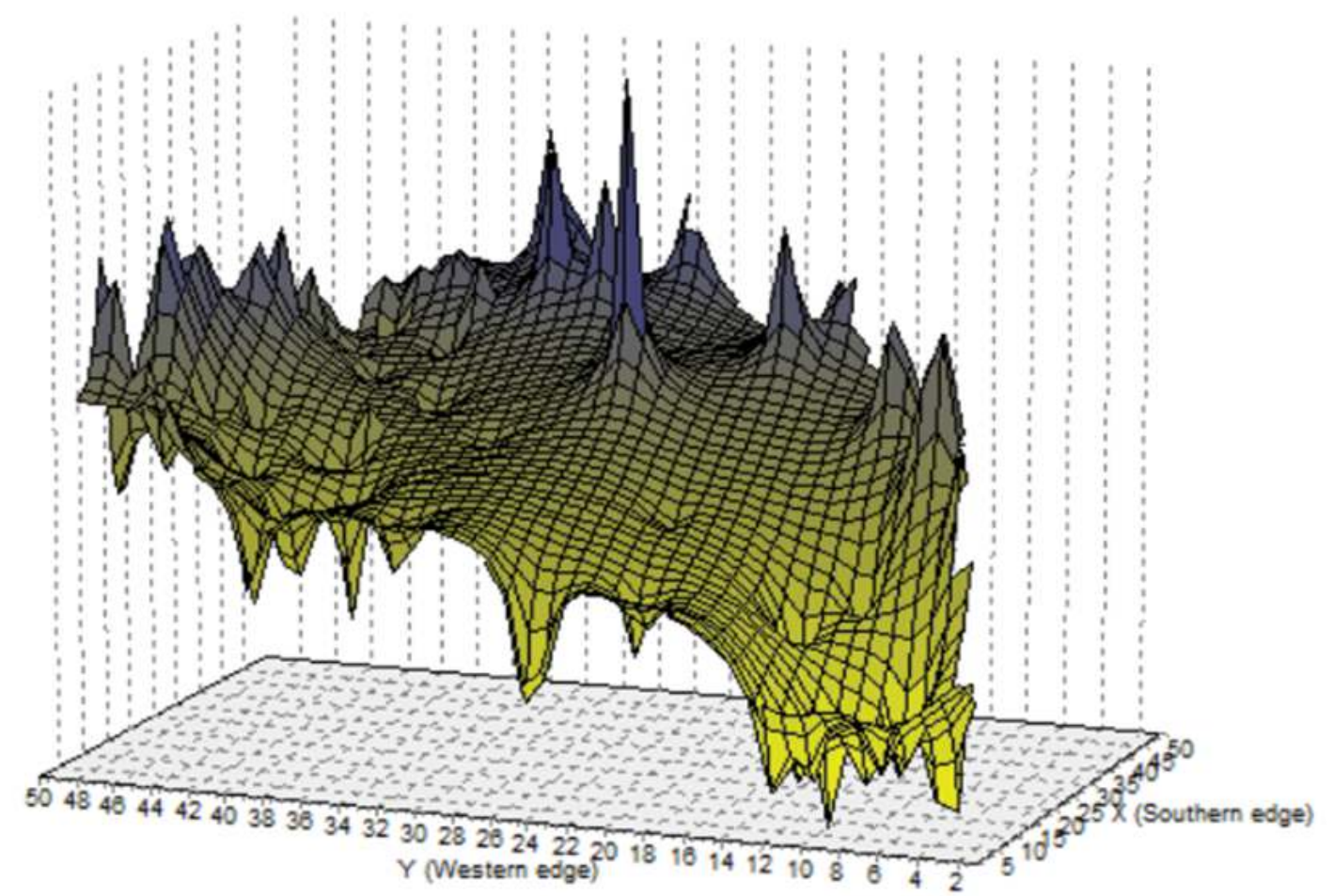

Figure 5 Landscape genetic shape plot of 36 silver fir population. $\mathrm{X}$ and $\mathrm{Y}$ axes correspond to geographic coordinates and the $\mathrm{Z}$ axis correspond to genetic distances between individuals. Blue peaks indicate areas with high pairwise genetic distances and yelow valleys indicate areas with low pairwise genetic distances

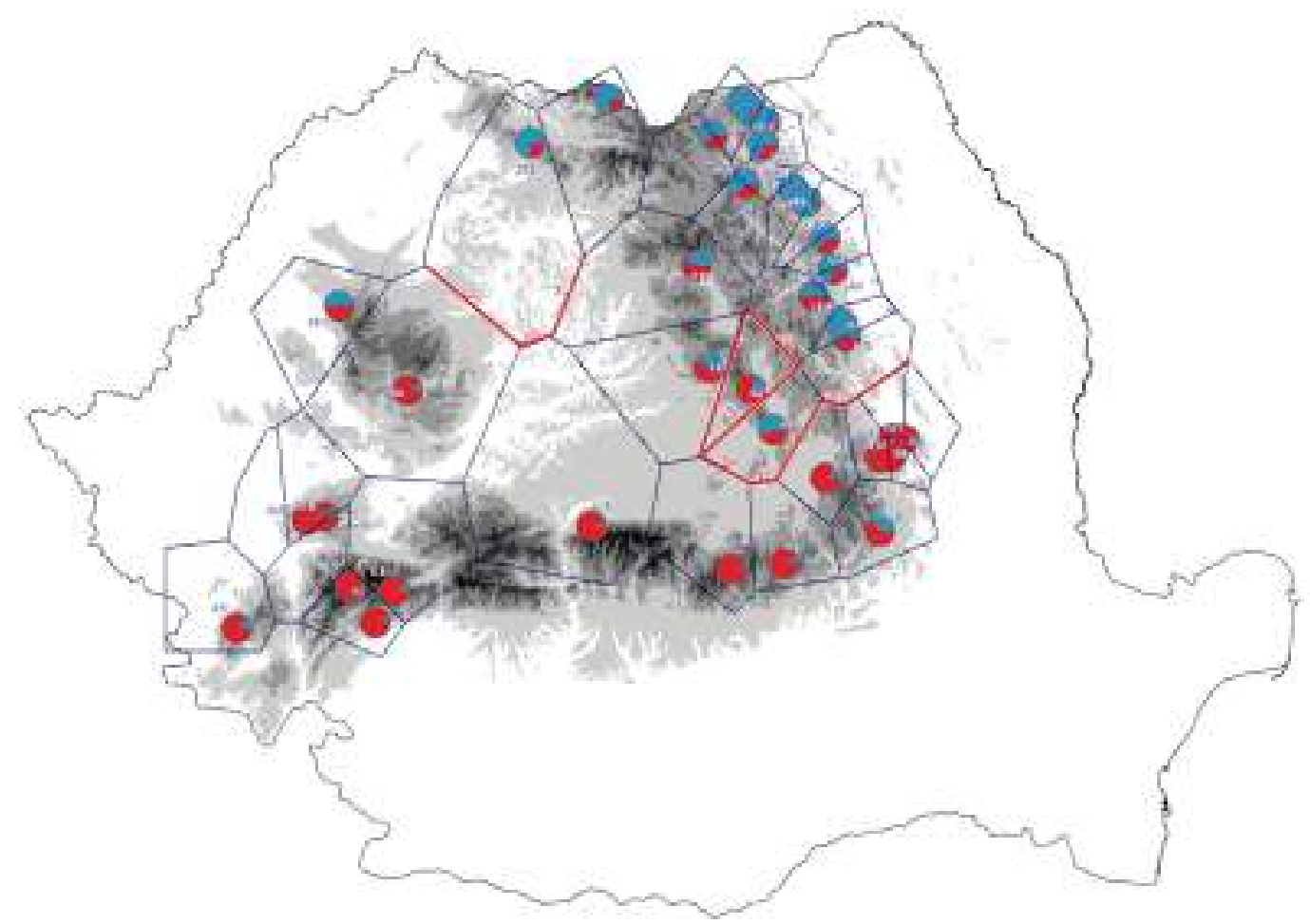

Figure 6 Map shows estimated populations structure for $\mathrm{K}=2$ and the detected genetic barrier. Red and blue clusters represent the genetic ancestry groups according to STRUCTURE analysis. Red lines show the main detected barriers with $>80 \%$ bootstrap support 
with two larger clusters containing populations from Curvature Carpathians and Banat Mountains and other four subgroups related to the Eastern Carpathians region; otherwise, the highest number of clusters inferred by STRUCTURE is six (Figure 4b).

\section{Landscape genetics}

The IBD pattern revealed by Mantel test indicated a weak, but significant correlation between genetic differentiation $\left(F_{S T}\right)$ and geographic distances $(r=0.359, P=0.010)$ when considering all the populations, slightly higher and significant for populations of cluster blue (Eastern Carpathians) $(r=0.490, P=0.0001)$, and lower, but also significant for cluster red (South-western Carpathians) $(r=0.297$, $P=0.005)$.

A pattern which is largely consistent with the Neighbour-joining analysis resulted from the genetic landscape shape analysis (Figure 5 ), with the south-western populations (Banat Mountains) showing a weak differentiation (e.g. the surface plot of genetic distances drop in this group), than the two other regions with a pronounced differentiation, one in the south-eastern part of distribution (CC Carpathians) and another in the north-eastern part.

Results from the STRUCTURE and NJ tree revealed clear genetic differentiation between north-eastern and southern populations (Figure 6) and in order to detect genetic barriers between these groups of populations the Barrier analysis based on Nei's genetic distances $\left(D_{A}\right)$ was used. The results indicate the existence of two major barrier. The first and most significant barrier $(100 \%$ bootstrap probability) (Figure 6) appeared between south-western and north-eastern populations and is concordant with the Transylvanian Plateau. The second barrier separated the Inner Eastern population FRU from all the others with $100 \%$ support, this barrier going further ( $80 \%$ bootstrap support) and dividing the eastern populations, from those of the Curvature Carpathians.

\section{Discussion}

\section{Population genetic diversity}

Our study on the genetic variation of Silver fir in the Romanian Carpathians, which overlaps with the south-eastern species distribution limit, revealed high genetic diversity and low genetic differentiation, as expected in conifer populations (Petit \& Hampe, 2006). Although different sets of microsatellites were employed, most of the populations revealed higher levels of genetic diversity, compared to those previously reported for Silver fir in Europe (Cvrckova et al. 2015, Popovic et al. 2017, Piotti et al. 2017). The expected heterozygosity $\left(H_{e}=0.810\right)$ obtained in the present study was higher than values reported by Gömöry et al. (2012) for Carpathians silver fir populations which found 0.680 for Balkan lineage, respectively 0.641 for Central European lineage. The recent study of Belleti et al. (2017), comprising 45 populations from Italy, the mean expected heterozygosity was 0.724 , while the observed heterozygosity was only 0.563 . In terms of private alleles, the same authors identified only two out of 45 populations that harboured two private alleles and 12 populations harboured one allele.

Sancho-Knapik et al. (2014) studied the genetic structure of ten populations from the western rear edge in the Spanish Pyrenees and compared them to two German populations and found that Spanish populations show a lower genetic diversity and a high genetic differentiation.

Based on the fixation index $\left(F_{S T}\right)$ the overall observed genetic differentiation in our study is relatively low, only $1,4 \%$ of the total genetic variation being due to differences among populations. For Italy, Belleti at al. (2017) found that about $8 \%$ of the genetic diversity is among populations, but this is explained by the fact that many populations have remained isolated for a long time, which is not the case for the Romanian silver fir populations. For Czech 
silver fir populations the $F_{S T}$ value ranged from 0.015 to 0.036 , comparable (Cvrčková et al. 2015) our values. For 14 Romanian population and one Bulgarian populations, Postolache et al. (2016) found a mean value for $F_{S T}$ of 0.018 . AMOVA confirmed the low degree of differentiation between provenances and genetic clusters, but the variance among populations within clusters $\left(F_{S C}\right)$ is almost equal to that obtained by Gömöry et al. (2012) 1,35\% for the two different mitochondrial lineage.

The geographical distribution of genetic diversity contradicts the core - peripheral hypothesis, according to which peripheral populations are expected to hold lower levels of genetic diversity within populations (Lesica \& Allendorf 1995, Eckert et al. 2008, Duncan et al. 2015), our eastern peripheral populations retaining the highest level of genetic diversity, both allelic richness and heterozygosity. However, some exceptions are registered in the populations sampled in the south-eastern region (CAI, CAS, VID and SOV) and in other few peripheral populations (MAL, RAS and $\mathrm{MOI}$ ), as allelic richness is below general average. Identification of centers of neutral diversity, as in the eastern Carpathians, suggesting that these peripheral populations possess high evolutionary potential. In fact, some of this populations (SOL, RAS, FRU) recognized as edaphotypes (high adaptability to hydrophilic soil) could show the adaptative imprint on a specific environment and the selection pressure could generate local adaptation. This would be an interesting case to be looked at using adaptative markers.

A decrease in genetic diversity along the Southern Carpathians (from east to west) coincides with a stronger fragmentation of the distribution area, which makes the populations more susceptible to the loss of genetic diversity. With only two exceptions (AVR and LUP), all the southern populations show a slight excess of homozygotes, which implies increased mating between relatives.

\section{Landscape genetics}

The distribution of the genetic clusters is related to the main bio-geographical regions described for the Romanian Carpathians (Georgescu \& Doniţă 1965) and corresponds broadly with the phylogeographical model identified for alpine plants (Ronikier 2011, Hurdu et al. 2016). Only a few studies investigated genetic differentiation within the South-Eastern Carpathians (the largest part of the Carpathians).

The genetic landscape shape analysis revealed an area with a high degree of differentiation, the second barrier between the genetic groups (more complex than the first), being largely congruent with the border between the Curvature Carpathians and Eastern Carpathians. This region is characterized by lower altitude, which does not generate a barrier to gene flow; a potential explanation could be the existence of cryptic microrefugia in the Eastern and Southern Carpathians and limited gene flow between these regional gene-pools.

The studies conducted so far (Konnert \& Bergmann, 1995; Fady et al., 1999; Liepelt et al., 2009; Gömöry et al., 2004, 2012., Piotti et al., 2017 etc.) consider that the current genetic structure of Silver fir populations has been shaped by the postglacial recolonization routes, and the migration history seems to be the main factor driving genetic differentiation rather than recent adaptation (Konôpková et al. 2019) or human activities. It is commonly accepted that for Silver fir the Balkan refugium down to Southern Greece is the source for the recolonization of South-east Europe (Konnert \& Bergmann 1995; Terhürne-Berson et al. 2004). Silver fir from this region represents a separate mitochondrial lineage (Ziegenhagen et al.2005, Liepelt et al. 2009). On the border between Romania and Ukraine a contact zone with the North-Apennine mitochondrial lineage is formed (Ziegenhagen et al. 2005, Liepelt et al. 2009) with few populations harbouring both mitochondrial lineages (Gömöry et al. 2012). Strong differentiation found between 
Bulgarian silver fir populations (southern Balkans) and the Romanian Carpathians (Konnert \& Bergmann, 1995, Postolache et al., 2016) and the geographical position of the western refugia leads to the hypothesis that probably only the northwest Balkan refugium determined the actual gene-pool of the Carpathian silver fir (Gömöry et al. 2012). It cannot be ruled out that a different refugium or even microrefugia have contributed to the colonization of Eastern Europe (Dobrowolska et al. 2017).

Palynological evidence indicates that silver fir appeared first in the Apuseni Mountains (Fărcaş et al. 2007; Feurdean \& Willis, 2008), from where they migrated to the north and east to the Carpathians. What is particular in the case of fir expansion in Romania is the late arrival and low postglacial migration rate, a distance of only $200 \mathrm{~km}$ between Apuseni Mountains and Eastern Romanian Carpathians being covered in about two millennia (Feurdean \& Willis, 2008 ), and probably there were other factors responsible for the slow eastward expansion, like competition with Picea abies, disturbances and last but not least, climate change.

Nuclear microsatellite data revealed admixture of two gene pools in the Northern Carpathians with one gene pool increasing and the other decreasing from north-west to south-east (Gömöry et al. 2012).

In the present study, the genetic signature of migration routes is very well highlighted by the genetic differences observed between the north-eastern Carpathians populations and south-western Carpathians ones. Based on nuclear microsatellite data and Bayesian analysis, two genetic clusters were identified in the Romanian Carpathians, one homogeneous cluster which corresponds to the southern part of the distribution range, and the second one, more heterogeneous which includes north-eastern populations. Therefore, north-eastern Carpathians populations have a high degree of admixture, most likely due to pronounced gene flow through pollen from west glacial refugium favoured by the orography of these mountains
(NW to SE orientation) and wind directions (predominantly from the North). Similar patterns in genetic structure along the Carpathians have been observed in other conifer species. In Picea abies, Tollesfrud et al. (2008) indicated the existence of a glacial refuge in southern Carpathians, hypothesis also supported by palynological evidence (Feurdean et al. 2007), while in Scots pine, the populations of Apuseni Mountains are differentiated from the populations of Eastern Carpathians, with the identified barriers suggesting an existence of a refuge in the Eastern Carpathians (Gy Toth et al. 2017).

Recolonization of Romanian Carpathians most probably occurred through seed from Balkan refugia (Balkan mitochondrial lineages) northward until the border to Ukraine forming a contact zone to the Apennine mitochondrial lineages. Pollen flow from the north might have led to the current picture of decreasing admixture proportions in silver fir populations from Northern to Southern Romanian Carpathians.

\section{Management and conservation implications}

Our study suggests three distinct hot-spots of genetic diversity in the (Romanian) Eastern Carpathians: the northern group (STB, POI, DEM, PUT, MAR), the eastern group (BRA, GAR, MOI, TAZ) and the southern population AVR. Although the genetic differentiation is low, the genetic structure of Silver fir populations is not as homogeneous as expected (especially in the NE Carpathians), therefore any management and conservation strategy including ex situ conservation, breeding programs, translocation and rezilience programs need to consider this distinctiveness of the identified genetic groups. Due to its relatively low genetic diversity, populations from Banat Mountains (ANI) which might be vulnerable to future environmental change, require a special attention (e.g. an intensive genetic monitoring and urgent measures to increase the genetic diversity).

A mix of environmental conditions and ge- 
netic specificity must be considered for delineating seed zones and designation of seed sources. Our study shows that the diversity of climatic, edaphic and topographic conditions can influence the population differentiation at regional scales and, although the provenance regions are well represented across Romania and the existing Silver fir seed sources are more than enough (about 4000 ha of selected seed sources) (Pârnuţă et al. 2012), the ecological particularities of the place where the forest reproductive material is to be used are not always considered. As pointed out before, the edaphic ecotypes could have certain genetic features which can be analyzed in more detail based on adaptive markers.

\section{Conclusions}

The genetic structure of the Eastern peripheral populations suggests an introgression zone with decreasing admixture proportion from north-west to south-east of the Romanian Carpathian mountain with topography and the regional climate playing an important role.

The silver fir populations from the eastern limit of its distribution hold high potential to mitigate the negative effects of climate warming, being valuable genetic resources in the context of global change.

Despite slight gradients of genetic diversity werefound and weak genetic differentiation was very weak, the distribution pattern of genetic variation at local, regional and country scale could and should be considered for appropriate management of forest genetic resources and development of strategy for conservation of valuable gene pools.

\section{Acknowledgments}

The research was carried out within a GENCLIM project funded by Executive Agency for Higher Education, Research, Development and Innovation, in PN II Programme. We are grateful to Dr. Monika Konnert for her valuable comments of the early version of this manuscript. We thank to the lab staff of the Bavarian Office for Forest Genetics in Teisendorf for their support. The visit and part of the genetic analysis were financially supported by the Bavarian State Chancellory.

\section{References}

Babicki S, Arndt D, Marcu A, Liang Y, Grant J.R, Maciejewski A, Wishart D.R.(2016). Heatmapper: web-enabled heat mapping for all. Nucleic Acids Research 2016 May 17 (epub ahead of print). DOI: 10.1093/nar/ gkw419

Barbu I., Barbu C., 2005. Silver fir (Abies alba Mill.) in Romania. Editura Tehnică Silvică, 220 p.

Barbu I., Curcă M., Ichim V., Barbu C., 2015. Changes in the forest cover of Bukowina between 1775 and 2012. Revista de Silvicultură și Cinegetică Anul XX (37): 1930.

Belletti P., Ferrazzini D., Ducci F., De Rogatis A., Mucciarelli M., 2017. Genetic diversity of Italian populations of Abies alba. Dendrobiology 77: 147-159. DOI: 10.12657/denbio.077.012

Bosela M., Lukac M., Castagneri D., Sedmák R., Biber P., Carrer M., Konôpka B., Nola P., Nagel T.A., Popa I., Roibu C.C., Svoboda M., Trotsiuk V., Büntgen U., 2018. Contrasting effects of environmental change on the radial growth of co-occurring beech and fir trees across Europe. Science of the Total Environment 615: 1460-1469. DOI: 10.1016/j.scitotenv.2017.09.092

Cheddadi R., Birks H. J. B., Tarroso P., Liepelt S., Gömöry D., Dullinger S., Meier E.S., Hülber K., Maiorano L., Laborde H., 2014. Revisiting tree-migration rates: $A b$ ies alba (Mill.), a case study. Vegetation History and Archaeobotany 23: 113-122. DOI: $10.1007 / \mathrm{s} 00334-$ 013-0404-4

Ciocîrlan E., Sofletea N., Ducci F., Curtu A.L., 2017. Patterns of genetic diversity in European beech (Fagus sylvatica L.) at the eastern margins of its distribution range. iForest 10(6): 916-922. DOI: 10.3832/ifor2446010

Cremer E, Liepelt S, Sebastiani F, Buonamici A, Michalczyk M, Ziegenhagen B, Vendramin GG, (2006). Identification and characterization of nuclear microsatellitesloci in Abies alba Mill. Molecular Ecology Notes 6: 374-376. DOI: 10.1111/j.1471-8286.2005.01238.x

Diaconeasa B., Fărcaş S., 2001. Istoricul brădetelor din România, descifrat prin metoda polen-analitică. Studia Universitatis “Babeş-Bolyai”, Biologia 3-20.

Dieringer D., Schlötterer C., 2003. Microsatellite analyser (MSA): a platform independent analysis tool for large 
microsatellite data sets. Molecular Ecology Notes 3: 167-169. DOI: 10.1046/j.1471-8286.2003.00351.x

Dumolin S, Demersure B, Petit RJ (1995). Inheritance of chloroplast and mitochondrial genomes in pedunculate oak investigated with an efficient PCR method. Theoretical and Applied Genetics 91: 1235-1256. DOI: 10.1007/BF00220937

Duncan S.I., Crespi E.J., Mattheus N.M., Rissler L.J., 2015. History matters more when explaining genetic diversity within the context of the core-periphery hypothesis. Molecular Ecology. DOI: 10.1111/mec.13315

Eckert C.G., Samis K.E., Lougheed S.C., 2008. Genetic variation across species geographical ranges, the central-marginal hypothesis and beyond. Molecular Ecology 17: 1170-1188. DOI: 10.1111/j.1365294X.2007.03659.x

Eckert C.G., Samis K.E., Lougheed S.C., 2008. Genetic variation across species geographical ranges: the central-marginal hypothesis and beyond. Molecular Ecology 17: 1170-1188. DOI: 10.1111/j.1365294X.2007.03659.x

Fărcaş S., Tanţău I., Bodnariuc A., Feurdean A., 2007. L'histoire des forets et du paléoclimat Holocène dans les Monts Apuseni. Contribuţii Botanice 42 (1): 115126.

Fărcaș S., Tanțău I., Mândrescu M., Hurdu B., 2013. Holocene vegetation history in the Maramureș Mountains (Northern Romanian Carpathians). Quaternary International 293: 92-104. DOI: 10.1016/j.quaint.2012.03.057

Feurdean A., Willis K.J., 2008: Long-term variability of Abies alba in NW Romania: Implications for its conservation management. Diversity and Distributions 14 : 1004-1017. DOI: 10.1111/j.1472-4642.2008.00514.x

Feurdean A., Tanțău I., 2017. The Evolution of Vegetation from the last glacial maximum until the present. In: Radoane M., Vespremeanu-Stroe A., (ed.): Landform Dynamics and Evolution in Romania. Springer International Publishing Switzerland. DOI: 10.1007/978-3319-32589-7 4

Francis R. M, (2016). Pophelper: An R package and web app to analyse and visualise population structure." Molecular Ecology Resources. DOI: 10.1111/17550998.12509

Gömöry D., Paule L., Krajmerova D., Romšaková I., Longauer R., 2012. Admixture of genetic lineages of different glacial origin: a case study of Abies alba Mill. in the Carpathians. Plant Systematics and Evolution 298 (4): 703-712. DOI: 10.1007/s00606-011-0580-6

Goudet J (1995). FSTAT (Version 1.2): a computer program to calculate F-statistic. Journal of Heredity 86 : 485-486. DOI: 10.1093/oxfordjournals.jhered.a111627

Gubler M., Henne P.D., Schworer C., Boltshauser-Kaltenrieder P., Lotter A.F., Bronnimann S., Tinner W., 2018. Microclimatic gradients provide evidence for a glacial refugium for temperate trees in a sheltered hilly landscape of Northern Italy. Journal of Biogeography 45(11): 2564-2575. DOI: 10.1111/jbi.13426

Gy Tóth E., Vendramin G.G., Bagnoli F., Cseke K., Höhn
M., 2017. High genetic diversitz and distinct origin of recentlz fragmented Scots pine (Pinus sylvestris L.) populations along the Carphatians and the Pannonian Basin. Tree Genetics \& Genomes 13: 47. DOI: 10.1007/ s11295-017-1137-9

Hampe A., Petit R.J., 2005. Conserving biodiversity under climate change: the rear edge maters. Ecology Letters 8: 461-467. DOI: 10.1111/j.1461-0248.2005.00739.x

Hansen OK, Vendramin GG, Sebastiani F, Edwards KJ, (2005). Development of microsatellites markers in $A b$ ies nordmanniana (Stev.) Spach and cross-species amplifications in Abies genus. Molecular Ecology Notes 5: 784-787. DOI: 10.1111/j.1471-8286.2005.01062.x

Howe G.T., Aitken S.N., Neale D.B., Jermstad K.D., Wheeler N.C., and Chen T.H.H., 2003. From genotype to phenotype: unraveling the complexities of cold adaptation in forest trees. Canadian Journal of Botany 81: 1247-1266. DOI: 10.1139/b03-141

Hurdu B.-I., Escalante T., Puşcaş M., Novikoff A., Bartha L., Zimmermann N.E., 2016. Exploring the different facets of plant endemism in the South-Eastern Carphatians: a manifold approach for the determination of biotic elements, centres and areas of endemism. Biological Journal of the Linnean Society 119: 649-672. DOI: 10.1111/bij.12902

Konnert M., Bergmann F., 1995. The geographical distribution of genetic variation of silver fir (Abies alba, Pinaceae) in relation to its migration history. Plant Systematics and Evolution 196 (1): 19-30. DOI: 10.1007/ BF00985333

Konôpková A., Krajmerova D., Kurjak D., Kmet J., Pšidova E., Kučerová J., Hrivnák M., Longauer R., Ditmarova L., Gömörz D., 2019. Nucleotide polymorphisms associated with climate and physiological traits in silver fir (Abies alba Mill.) provenances. Flora 250: 37-43. DOI: 10.1016/j.flora.2018.11.012

Lesica P., Allendorf F.W., 1995. When are peripheral populations valuable for conservation? Conservation Biology 9: 753-760. DOI: 10.1046/j.15231739.1995.09040753.x

Lucău-Dănila A., 1991. Variabilitatea genetică a bradului. Universitatea "Transilvania” Brașov. Teza de doctorat. (in Romanian).

Magyari E.K., Jakab G., Bálint M., Buczkó K., Braun M., 2012. Rapid vegetation response to Lateglacial and early Holocene climatic fluctuation in the South Carpathian Mountains (Romania). Quaternary Science Reviews 35: 116-130. DOI: 10.1016/j.quascirev.2012.01.006

Manni F., Guerard E., Heyer E., 2004. Geographic patterns of (genetic, morphologic, linguistic) variation: how barriers can be detected by using Monmonier's algorithm. Human Biology 76: 173-190. DOI: 10.1353/ hub.2004.0034

Marchi M., Nocentini S., Ducci F., 2016. Future scenarios and conservation strategies for a rear-edge marginal population of Pinus nigra Arnold in Italian central Apennines. Forest Systems 25(3), e072, 12 pages. DOI: $10.5424 / \mathrm{fs} / 2016253-09476$ 
Meirmans P.G., 2012. The trouble with isolation by distance. Molecular Ecology 21: 2839-2846. DOI: 10.1111/j.1365-294X.2012.05578.x

Mihai G., Bîrsan M-V., Dumitrescu A., Alexandru A., Mirancea I., Ivanov P., Stuparu E., Teodosiu M., Daia M., 2018. Adaptive genetic potential of European silver fir in Romania in the context of climate change. Annals of Forest Research 61(1): 95-108. DOI: 10.15287/ afr.2018.1021

Ortego J., Riordan E.C., Gugger P.F., Sork V.L., 2012. Influence of environmental heterogeneity on genetic diversity and structure in an endemic southern Californian oak. Molecular Ecology 21: 3210-3223. DOI: 10.1111/j.1365-294X.2012.05591.x

Pârnuţă G., Stuparu E., Budeanu M., Scărlătescu V., Marica F.-M., Lala I., Tudoroiu M., Lorenţ A., Filat M., Teodosiu M., Nica M.S., Chesnoiu E.N., Pârnuţă P., Mirancea I., Marcu C., Pepelea D., Dinu C., Marin S., Daia M., Dima G., Șofletea N., Curtu A.-L., 2012. Catalogul Naţional al materialelor de bază pentru producerea materialelor forestiere de reproducere din România. Editura Silvică, Bucureşti, 304 p.

Peakall R., Smouse P.E., 2005. GenAlEx 6.5: genetic analysis in Excel. Population genetic software for teaching and research-an update. Bioinformatics 2: 2537-2539. DOI: $10.1093 /$ bioinformatics/bts460

Postolache D., Popescu F., Pitar D., Apostol E.N., Iordan A., Avram M., Iordan O., Zhelev P., 2016: Originea, evoluția și structura genetică a brădetelor din România evaluate prin intermediul markerilor moleculari. Revista de Silvicultură și Cinegetică Anul XXI (38): 8-14.

Ronikier M., 2011. Biogeography of high-mountain plants in the Carpathians: An emerging phylogeographical perspective. Taxon 60(2): 373-389. DOI: 10.1002/ tax.602008

Rousset F (2008). Genepop'007: a complete reimplementation of the Genepop software for Windows and Linux. Molecular Ecology Resources 8: 103-106. DOI: 10.1111/j.1471-8286.2007.01931.x

Ruosch M., Spahni R., Joos F., Henne P.D., Knaap W.O., Tinner W. 2016. Past and future evolution of $A b$ ies alba forests in Europe-comparison of a dynamic vegetation model with palaeo data and observations. Global Change Biology 22(2): 727-740. DOI: 10.1111/ gcb. 13075

Samartin S., Heiri O., Kaltenrieder P., Kühl N., Tinner W., 2016. Reconstruction of full glacial environments and summer temperatures from Lago della Costa, a refugial site in Northern Italy. Quaternary Science Reviews 143: 107-119. DOI: 10.1016/j.quascirev.2016.04.005

Sancho-Knapik D., Peguero-Pina J.J., Cremer E., Camarero J., Cancio Á., Ibarra N., Konnert M., Pelegrín E., 2014. Genetic and environmental characterization of Abies alba Mill. populations at its western rear edge. Pirineos. 169. e007. 10.3989/Pirineos.2014.169007. DOI: 10.3989/Pirineos.2014.169007
Savolainen O., 1996. Pines beyond the polar circle: Adaptation to stress conditions. Euphytica 92(1-2): 139-145. DOI: $10.1007 / \mathrm{BF} 00022839$

Şofletea N, Curtu AL, 2001. Dendrologie [Dendrology]. Editura Pentru Viaţă, Braşov, România, pp.300. [in Romanian].

Tanțău I., Feurdean A., de Beaulieu J.-L., Reille M., Fărcaș S., 2011. Holocene vegetation history in the upper forest belt of the Eastern Romanian Carpathians. Palaeogeography, Palaeoclimatology, Palaeoecolgy 309: 281-290. DOI: 10.1016/j.palaeo.2011.06.011

Tanțău I., Reille M., de Beaulieu J.L., Fărcaș S., Goslar T., Paterne M., 2003. Vegetation history in the eastern Romanian Carpathians: pollen analysis of two sequences from the Mohos crater. Vegetation History and Archeobotany 12: 113-125. DOI: 10.1007/s00334-003-0015-6

Terhürne-Berson R., Litt T., Cheddadi R., 2004. The spread of Abies throughout Europe since the last glacial period: combined macrofossil and pollen data. egetation History and Archeobotany 13: 257-268. DOI: 10.1007/s00334-004-0049-4

Tinner W., Colombaroli D., Heiri O., Henne P.D., Steinacher M., Untenecker J., Vescovi E., Allen J.R.M., Carraro G., Conedera M., Fortunat J., Lotter A.F., Lutherbacher J., Samartin S., Valsecchi V., 2013. The past ecology of Abies alba provides new perspectives on future responses of silver fir forests to global warming. Ecological Monographs 83: 419-439. DOI: 10.1890/122231.1

Tollesfrud M.M., Kissling R., Gugerli F., Johnsen Ø., Skrøppa T., Cheddadi R., Van der Knaap W.O., Latalowa M., Terhürne-Berson R., Litt Th., Geburek Th., Brochman C., Sperisen C., 2008. Genetic consequences of glacial survival and postglacial coloniyation in Norway spruce: combined analzsis of mitochondrial DNA and fosil pollen. Molecular Ecology 17: 4134-4150. DOI: $10.1111 /$ j.1365-294X.2008.03893.x

Van Oosterhout C, Hutchinson WF, Wills DPM, Shipley P (2004). Micro-checker: software for identifying and correcting genotyping errors in microsatellites data. Molecular Ecology Notes 4: 535-538. DOI: 10.1111/j.1471-8286.2004.00684.x

Vitasse Y., Bottero A., Rebetez M.,Conedera M., Augustin S., Brang P., Tinner W., 2019. What is the potential of silver fir to thrive under warmer and drier climate? European Journal of Forest Research 138(4): 547-560. DOI: $10.1007 / \mathrm{s} 10342-019-01192-4$

Wang I. J., 2013. Examining the full effect of landscape heterogeneity on spatial genetic variation: a multiple matrix regresion approach for quantifying geographic and ecological isolation. Evolution 62(12): 3403-3411. DOI: 10.1111/evo.12134

Ziegenhagen B., Fady B., Kuhlenkamp V., Liepelt S. 2005. Differentiating groups of Abies species with a simple molecular markers. Silvae Genetica 54 (3): 123126. DOI: $10.1515 / \mathrm{sg}-2005-0019$ 